\title{
The short-term and long-term effects of institutional reforms on party system nationalization
}

\author{
Pablo Simón \\ Social Sciences Department \\ Universidad Carlos III de Madrid \\ Calle de Madrid, 126, 28903, Getafe \\ Madrid, Spain \\ e-mail: pablo.simon@uc3m.es \\ Tel: +34659170842 \\ Marc Guinjoan \\ Departament of Political Sciences and Public Law \\ Universitat Autònoma de Barcelona \\ 08193, Bellaterra (Cerdanyola del Vallès) \\ Barcelona, Spain \\ e-mail: marc.guinjoanc@uab.cat
}

\begin{abstract}
The impact of institutions on party system nationalization has traditionally been examined in a cross-national fashion. However, while in some cases institutional reforms may be expected to immediately affect party nationalization, in others, changes might take place over subsequent elections. In this paper, we argue that reforms affecting mainly elite coordination -such as decentralization-will take a longer time to have an impact on party system nationalization than reforms related to the mechanical effects of electoral laws, i.e. changes in the electoral system. In order to test this argument, we use error-correction models to test the impact of electoral reforms on party system nationalization in democratic elections held in 22 Western and Eastern European countries from 1945 to 2012. In accordance with our arguments, we show that both decentralization and the number of districts elected in the legislative power will have an impact on party system nationalization, but that the impact of the latter will manifest itself earlier.
\end{abstract}

Keywords: party system nationalization, error-correction models, institutional reforms, decentralization, number of districts. 


\section{Introduction}

Institutions are central in explaining why some countries exhibit more nationalized party systems than others (Cox, 1997; Golosov, 2016a; Hicken and Stoll, 2016; Jesse, 1999; Jones and Mainwaring, 2003; Morgenstern et al., 2011). Specifically, two sets of arrangements have been suggested as being most relevant. Firstly, political decentralization has been said to erode party system nationalization (Brancati, 2008; Chhibber and Kollman, 1998, 2004; Golosov, 2016a; Harbers, 2010). Secondly, electoral systems with small district magnitude or large number of districts are expected to deter nationalization, while upper tiers and national thresholds are expected to increase nationalization.

Nevertheless, the empirical findings are, at best, mixed. For instance, district magnitude has been shown to erode nationalization in certain pieces of research (Cox and Knoll, 2003), while in others the opposite direction has been suggested (de Miguel, 2016; Lublin, 2016). Similarly, the effect of the percentage of seats elected in the upper tier is not clear (Simón, 2013), and research addressing the relationship between decentralization and nationalization has found no conclusive evidence in Central and Eastern Europe (Bochsler, 2010b) or in Western Europe (Lago-Peñas and Lago-Peñas, 2011).

These mixed results might be driven by the very nature of the research carried out to date, which has mainly relied on static analyses. Institutions are presumed to be stable over time; while this approach may seem sound, changes actually take place more often than commonly recognized (Bedock, 2015). For example, although major electoral reforms are rare in Western democratic countries, small changes are commonplace: district magnitude, ballot structure and boundaries are often revisited, as well as the number of seats allocated in different tiers (Jacobs and Leyenaar, 2011). 
Similarly, over the last decades, Europe has experienced what has been labelled an "era of regionalization", which has increased political and fiscal decentralization (Hooghe et al., 2010).

In this paper, we use institutional reforms to address the relationship between institutions and party system nationalization from a dynamic perspective. This strategy will allow us to better identify the actual impact of institutional settings on party systems, as well as to better determine the speed at which party systems adapt to institutional reforms (Bowler and Donovan, 2013). Studies on party system nationalization have focused on pooled time-series cross-national evidence, but for the most part they have overlooked the possibility of changes taking place after different elections. The literature has only recently started to consider the possibility of institutional reforms not necessarily having consequences in the elections taking place immediately after the reform, but rather causing changes over a longer time span (see, for instance, Best, 2012).

To address this idea empirically, we generate a series of error-correction models with data from 22 European countries that have undergone institutional reforms, in order to capture the short-term and long-term effects of reforms on party system nationalization. Using two different measures of party nationalization, we show that decentralization shows its effects on party system nationalization over a longer period of time, while reforms in the number of districts elected have effects which take place in a shorter time span.

The paper is structured as follows: in the following section the main arguments are presented; in section three we introduce the methods and empirical indicators; in the fourth section the main results are discussed, and in the last section we reach our conclusions. 


\section{Arguments}

Despite the long tradition of the concept of party system nationalization (Rokkan, 1970; Schattschneider, 1960), it is only since the 2000s that it has re-entered the research agenda (Caramani, 2004; Chhibber and Kollman, 1998, 2004; Cox, 1999; Jones and Mainwaring, 2003). This concept refers to the extent to which "politicians seeking election to the national legislature from different districts (...) run under a common party label" (Cox, 1997, p. 186). This territorial connection of local party systems is usually conceptualized as a continuum depending on the degree to which parties are uniformly successful in winning votes across districts (Bochsler, 2010a; Harbers, 2010; Moenius and Kasuya, 2004). Strongly nationalized party systems are those in which each party is similar across geographic units, while weakly nationalized party systems exhibit great variation in the vote share of parties across sub-national units (Kasuya and Moenius, 2008).

Despite the relevance of territorial cleavages at determining the degree of party system nationalization ${ }^{1}$, the greater part of the literature has been focused on the role of institutions (Golosov, 2016a; Morgenstern et al., 2011). One of the most important institutional variables that explain party system nationalization has been political decentralization. The degree of decentralization determines where political decisions are taken, and therefore, the more centralized the power is, the higher the incentives for local parties and candidates to join into national parties, and voters to support them instead of backing a local but nationally uncompetitive party.

The causal mechanisms linking the level of decentralization and party system nationalization are twofold. Firstly, voters are oriented towards the arena that affects their lives more, and, as the balance of power moves in favour of the central government, they will tend to support national parties which are able to deal with the 
policies that they care about (Chhibber and Kollman, 1998, 2004; Deschouwer, 2006). Secondly, since the national government is a bigger prize than the regional one, local candidates will prefer to join nationwide parties. This will provide them with greater influence in terms of policy-making and communication, and will eventually increase their electoral prospects (Chhibber and Kollman, 1998, 2004).

Conversely, when a country decentralizes, regional legislatures increase their power and make regional parties more likely to emerge and to participate in national politics, thus eroding party system nationalization (Brancati, 2008). There are two different reasons for this. Firstly, pre-existing regional parties will take advantage of the already created infrastructure at the regional level to also compete at the national level (Guinjoan, 2014, Chapter 3). Secondly, regional parties competing in the national arena will be able to influence the national agenda and policies through coalition bargaining in favour of their region (Falcó-Gimeno and Verge, 2013). Despite this last mechanism being partially different because it operates through regional parties, the implication leads us in the same direction: political decentralization inhibits the development of nationalized party systems (Harbers, 2010).

The second main institutional component affecting party system nationalization is the electoral system. The crucial element that relates the electoral system with party system size is district magnitude (Clark and Golder, 2006; Cox, 1997; Duverger, 1954; Lublin, 2016). Small district magnitude reduces the number of parties through the mechanical effect of electoral laws -the translation of votes into numbers of seats that prevents minor parties from achieving representation (Duverger, 1954)- and the psychological effect -parties' and voters' anticipation of the mechanical effect. Then, under the assumptions of short-term instrumental rationality and perfect information (Cox, 1999), voters will be expected to desert minor parties through strategic voting, 
whereas parties will tend to coalesce or to withdraw from competition if they have no real chances of winning a seat (Cox, 1997, 1999).

Nevertheless, the effect of district magnitude on party system nationalization is still not clear. Cox and Knoll (2003) argue that district magnitude should have an impact on nationalization through the number of wasted votes generated by the electoral system. "Politicians representing minority viewpoints in low-magnitude districts may fall short of their district's threshold of representation and end up with nothing but wasted votes. Thus, they have a much greater incentive to combine votes across districts" (Cox and Knoll, 2003, p. 3). Conversely, large district magnitudes will reduce the number of wasted votes and will discourage parties from coalescing across districts, thus preventing party system nationalization.

However, Morgenstern, Swindle and Castagnola (2011) have argued exactly the opposite. According to them, district magnitude appears to be related positively with party nationalization, based on its connection with proportional representation (PR). In SMD electoral systems, parties need a plurality of votes to gain a seat and, therefore, they "may avoid spending the resources (good candidates, costs, and effort) to compete where they have little chance for winning" (Morgenstern et al., 2011, p. 1327). Moreover, under plurality rule, minor parties risk losing support due to the strategic defection of their voters, causing an uneven territorial distribution of electoral support (Bochsler, 2016). In contrast, in PR electoral systems, winning a seat requires less than a plurality of votes and therefore parties will have higher incentives to compete everywhere, to pursue a national strategy and to devote a similar number of resources across districts. Also, in proportional representation systems, coordination across districts will be more likely to take place, since parties "can reasonably expect to gain at least some votes in those districts that are not their natural stronghold" (de Miguel, 
2016). Then, the positive impact of district magnitude on party nationalization operates through parties' strategic entry, strategic voting and the allocation of resources.

District magnitude is intrinsically linked with the number of constituencies into which a polity is carved up. There are three different arguments that link an increase in the number of districts of a polity with lower party system nationalization. Firstly, some authors have argued that increasing the number of units makes the coordination between them more difficult (Harbers, 2010; Nikolenyi, 2009). Secondly, the existence of a high number of districts increases the likelihood that one of the constituencies is different from the others, thus boosting the costs of coordinating campaign strategies. In fact, "more districts should yield greater variability in terms of candidate qualities, which again should increase the distinctive of electoral districts" (Morgenstern et al., 2011, p. 1328). Thirdly, "compared to data from many small units, in a few larger territorial units electoral strongholds will not be any more as pronounced and not necessarily as recognizable" (Bochsler, 2010a, p. 163).

Finally, there is another element which could have an impact on the nationalization of the party system: the presence of an upper tier to pool districts' wasted or excessive votes. "Laws implementing upper tiers require an explicit legal linkage of the lists or candidates wishing to pool their votes at the stipulated higher level. Thus, they provide an obvious incentive to politicians to ally across district boundaries" (Cox, 1999, p. 157). When there are many seats allocated in the upper district there is a clear potential electoral gain to be obtained from competing in a national fashion and, therefore, we would expect the nationalization of the party system to increase.

Before moving onto the next section, it is necessary to consider the issue of reverse causality, a commonplace problem when analysing institutions. It is well known that parties are not simply the product of the incentives created by the existing electoral 
rules, but also by the rules implemented by the parties themselves (Benoit, 2007; Colomer, 2005; Remmer, 2008). It could be that the more fragmented or denationalized party systems are the ones implementing electoral reforms (Riera, 2013), or that the regional and local parties already existing in a polity are the ones pushing for an increase in the level of decentralization of the country. However, empirical evidence has shown that endogeneity is not of special concern in these cases since most institutions are in existence prior to reforms. Indeed, Best (2012) shows that electoral institutions are the ones that mainly shape party systems, whereas Brancati concludes that the relationship between this variable and denationalization is not endogenous (2008).

\section{Towards a dynamic explanation}

Research addressing the relationship between institutions and party system nationalization has mostly used a cross-national perspective. The longstanding assumption behind this idea is that electoral reforms will directly affect the incentives of parties to compete nationally, as well as affecting voting decisions. Nevertheless, this perspective may be biased if institutional changes do not have an immediate effect on the nationalization of the party system in the first election, but when the effect is distributed over subsequent elections (Riera, 2013; Tavits, 2008). To date, the majority of the research has underlined that the process of modernization and the inclusion of peripheries in the political process would lead to a progressive nationalization of the electorates (Bochsler, 2010b; Caramani, 2004). However, when institutions change, the equilibrium is temporarily disrupted; a new equilibrium is found further along, when voters and parties have adapted their behaviour to the incentives provided by the new rules. $^{2}$ 
Our argument is that the timing of the effects is driven by the extent to which the mechanical considerations of the reforms create urgency for adapting to the new rules (Cox, 1997, 1999). In the case of electoral reforms, both strategic entry and strategic voting are the product of repeated interactions in a context where the translation of votes into seats is driven by some degree of disproportionality (Riera, 2013). In this situation, the mechanical effect operates by pushing for a rapid coordination and change in the national/regional orientation of political parties. In fact, parties failing to anticipate the effect of electoral reforms will suffer important penalties in terms of representation (Andrews and Jackman, 2005). As a consequence, reforms affecting district magnitude or the number of districts will be expected to have an immediate effect on party elites and voters' strategic behaviour and, therefore, party system nationalization will quickly change to adapt to the new context.

However, other institutional reforms may have consequences on party system nationalization over a longer time span. This could be, firstly, because some institutional reforms entail a potential gain in terms of seats but do not put parties' electoral prospects at risk. For instance, when the number of seats allocated in the upper tier is increased, parties can consider cross-district alliances to gain extra seats in the legislature (Cox, 1999). However, this process is not automatic, but involves a second stage of coordination for which we expect a longer period of adaptation.

Secondly, when institutional reforms entail a reallocation of power across different levels, incentives for changing the structure of party competition are not immediate either. If centralization increases, it may take some time for local politicians to realise that the national level is now more powerful and that by competing under a national brand they will have better electoral prospects (Chhibber and Kollman, 1998). Similarly, if voters desert regional parties in favour of nationally competitive parties, 
they too may require some time to understand the new rules of the process. Moreover, in multilevel environments, voters require a learning process to understand where the power is allocated and who is responsible for each policy area (León, 2012). Thus, we can expect some time to pass until a new equilibrium is reached after the territorial reform.

The main contribution of the dynamic approach is not only that it sheds some light on the speed at which institutional reforms will affect party system nationalization, but also that it helps elucidate the direction of this impact. As for decentralization, some scholars have confirmed its effects at eroding party system nationalization, either alone (Brancati, 2008; Chhibber and Kollman, 1998; Golosov, 2016a; Harbers, 2010) or in interaction with the electoral system (Simón, 2013). However, other studies have failed to establish a direct causality (Bochsler, 2010b; Lago-Peñas and Lago-Peñas, 2011). Similarly, in the case of district magnitude, some studies have found that SMD systems and the presence of a large number of districts erode party system nationalization (Bochsler, 2016; de Miguel, 2016; Morgenstern et al., 2011), while others have found exactly the opposite (Cox and Knoll, 2003). Some authors have even found that this variable has a negligible impact on party system nationalization in comparison with other institutions (Hicken and Stoll, 2016).

To sum up, although institutions have been shown to affect party system nationalization, the literature has barely explored the speed at which different reforms will affect it. Hitherto we have argued that this will chiefly depend upon whether the reform affects (or not) the anticipation of the mechanical and the psychological effects among party elites and voters. When effects are immediate -such as reforms affecting electoral proportionality-, we can expect a rapid coordination; however, when reforms 
entail strategic considerations or coordination processes across districts, then we can expect the effect to be distributed over future elections.

Table 1 summarizes the expected impact of each institutional reform on party system nationalization -whether positive or negative- and the speed at which this impact will take place. We expect the impact caused by reforms on the percentage of seats elected in an upper tier and in the level of decentralization to take place over several elections; while the first will boost nationalization, the second one will decrease it. Additionally, an increase in the number of districts is expected to reduce party system nationalization quickly, whereas changes due to altering district magnitude will take place in the short term, but their impact is unclear.

[Table 1 about here]

\section{Data and methods}

In order to test hypotheses related to the dynamic effect of institutional change on party system nationalization, we will focus on data coming from electoral reforms that have been implemented in European countries. We will use two different measures of party system nationalization based on the Constituency-Level Elections Archive (CLEA) database. To date, the literature has used up to four different families of nationalization indices: indices of frequency; of variance; of distribution; and inflation measures (Bochsler, 2010a, pp. 159-160). Among these, there are over 16 different indices of static nationalization (see Bochsler, 2010a; Golosov, 2016b) and at least another one which is focused on inter-electoral nationalization (Morgenstern et al., 2011). From a conceptual point of view it can be argued that they are different types of measures (see 
Lago and Montero, 2014); therefore we will check the robustness of our estimates by using the two most popular measures among scholars, i.e. the inflation and the distribution indices.

Firstly, inflation measures (Cox, 1997, 1999) are based on the comparison between the party system at the national and at the district level. The most popular of these inflation indices is calculated as the difference between the effective number of parties at the national level and the average of the number of parties competing at the district (regional) level. ${ }^{3}$ Therefore, as deviation becomes higher, the inflation of the national party system also increases and nationalization is lower. This index, which we will label Party System Inflation (PSI), has been broadly employed and discussed in the literature (Bochsler, 2010a). It is operationalized as follows:

$$
P S I=E N P_{\text {nat }}-E N P_{\text {avg }}
$$

Where:

$\mathrm{ENP}_{\text {nat }}$ is the effective number of parties at the national level, and

$\mathrm{ENP}_{\text {avg }}$ is the average of the number of parties at the local level.

Secondly, we also employ the most recently created index in the literature, the Standardized and Weighted Party System Nationalization Score (PSNS). This indicator, which belongs to the family of distribution indices, is based on the transformation of a Gini coefficient into a measure of the territorial vote distribution of a political party. In the case of a homogeneous distribution (high party nationalization), each territorial unit will cast a number of votes for a particular political party that is approximately proportional to the unit's size, or the party will win a similar vote share in every territorial unit. In the case of heterogeneous vote distributions, however, most of the 
votes are concentrated in a few territorial units (Bochsler, 2010a). The index is operationalized as follows:

$$
\operatorname{PSNS}_{S W}=\sum_{1}^{n} P N S_{S W_{i} i} \times p_{i}
$$

Where:

PNS is the Party Nationalization Score standardized for the number of territorial units and weighted for the size of the territorial units. The variable is originally calculated as the inverse of the Gini coefficient $\left(1-\mathrm{G}_{\mathrm{i}}\right)$;

$\mathrm{p}_{\mathrm{i}}$ is the party's share of the national vote.

The sources for the independent variables are diverse. First, we operationalize the different electoral reforms with data coming from the Electoral System Changes in Europe project (ESCE). This project covers all cases of electoral system change in Europe from 1945. Several dimensions of the electoral system are taken into consideration, such as the number of districts, district magnitude or the percentage of seats elected in an upper tier. What is observed are legislative terms and the time span considered for the analysis of each country ranges from the second election after WWII (or the second election after the transition to democracy) and up to $2012 .^{4}$

As for the level of decentralization, we rely on the Regional Authority Index by Hooghe et al. (2008). This measure encompasses two different dimensions of regional authority: shared rule -competences are shared between the national and the regional government- and self-rule -competences are owned exclusively by the sub-national government. This measure allows us to overcome two common problems encountered by researchers working on decentralization. Firstly, in measuring decentralization, some scholars have taken into account only the level of expenditure and revenues of the sub- 
national institutions, while omitting other dimensions crucially related to the regional powers (Chhibber and Kollman 2004; Cox and Knoll 2003; Harbers 2010). Secondly, other scholars have simplified the measures of regional authority to mere dichotomous variables (Brancati, 2008), thus ignoring the rich variation in self-government over time and across different polities. The variable in our database ranges from 0 (e.g. the Czech Republic between 1992 and 1998, or Ireland between 1948 and 1987) to 32.2 (Belgium, 1991-1995), with the higher values corresponding to the most decentralized countries.

Consistent with previous research (see, for instance, Cox, 1997; Simón, 2016) we have logarithmically transformed the number of districts and the mean of district magnitude, in order to better identify a linear relationship with our dependent variables. Finally, the variable Upper Tier is the percentage of seats elected in the PR tier in mixed-member systems (MMS). The variable ranges from 0, corresponding to countries without MMS, to 60.66 (Austria, 2008). The source for the three variables is the Electoral System Changes in Europe (ESCE) project.

Table 2 summarizes the number of institutional changes experienced in the 22 countries in Western and Eastern Europe that have undergone reforms to their electoral systems or in their levels of decentralization, as well as the first election for which we have data and the number of elections included in the analysis.

[Table 2 about here]

Additionally, table 3 displays the summary statistics for the countries under analysis.

[Table 3 about here] 
In performing the empirical analysis, our strategy is to include all the institutional and organizational changes that have taken place, irrespective of the size of the shift. For instance, one of the major changes is the 1994 Italian electoral reform that substituted the PR system for a mixed-member system ${ }^{5}$; another is the substitution of the run-off system by a proportional system in the French Fifth Republic. We have included these major changes, along with smaller ones, such as minor adjustments in the number of constituencies (as in the United Kingdom) or in district magnitude (Sweden, Switzerland or Ireland).

Our strategy is quite similar in the case of decentralization reforms. ${ }^{6}$ The general trend has been to increase the powers of regional governments, but while there are countries that have suffered only minor changes in levels of decentralization (for instance, Austria in 1986 or Germany in 1990), in others there has been a drastic change (Italy, in 1972, with its process of regionalization; or Belgium with its major federal reform in the seventies).

\section{Error-correction models}

To assess the short-term and the long-term impact on party system nationalization caused by changes in the electoral system or in the level of decentralization of a country, we will make use of an error-correction model (ECM). Error-correction models are able to estimate the speed at which a given dependent variable changes, to ultimately return to an equilibrium situation after the administration of a treatment -in our case, an electoral reform or change in the level of decentralization- (De Boef and Keele, 2008).

The basic structure of an error-correction model is as follows: 


$$
\Delta Y_{t}=\alpha_{0}+\alpha_{1} Y_{t-1}+\beta_{0} \Delta X_{t}+\beta_{1} X_{t-1}+\varepsilon_{t}
$$

Where $\alpha_{1}$ (the lagged level of the dependent variable) represents the speed at which $\mathrm{X}$ and $\mathrm{Y}$ will return to an equilibrium situation after the administration of a treatment; $\beta_{0}$ captures the impact of a change of $\mathrm{X}$ on $\mathrm{Y}$ at time $=1$; while $\beta_{1} / \alpha_{1}$ will provide us with the long-run multiplier (LRM), i.e., the total change in $\mathrm{Y}$ distributed over future time periods which have occurred after several unit changes in X. We will directly estimate the LRM and its standard error through the transformation proposed by Bewley (1979).

The ECM will therefore allow us to assess the immediate effect of a change in the electoral system or in the level of decentralization on the two measures of party system nationalization, as well as the impact of this change upon subsequent elections, and also the total amount of change over several periods. We include fixed country effects in the models in order to allow the ECM to properly account for systematic differences in the dependent variable which are explained by idiosyncratic factors. ${ }^{7}$ The structure of the data, as well as the considerable stability of the country scores in the level of nationalization of the party system throughout the years, make the ECM perfectly suited for the purposes of this research. ${ }^{8}$

We will run four different specification models on Party System Inflation (PSI). The first includes only decentralization as a covariate, while the second and the third models include all variables related to the electoral system. Given the high correlation between the $(\log )$ number of districts and the (log) district magnitude $(-0.77$, significant at the 0.001 level), we only include one of these covariates in each model. Model four pools together all the independent variables except for the (log) district magnitude. We eliminate the $(\log )$ district magnitude and instead keep the $(\log )$ number of districts, given the higher predictive power of this later variable in the previous models.

Therefore: 
Model 1:

$\Delta$ PSI $_{t}=\alpha_{0}+\alpha_{1} D_{t-1}+\beta_{0} \Delta$ Decentralization $_{t}+\beta_{1}$ Decentralization $_{t-1}+\varepsilon_{t}$

Model 2:

$\Delta P S I_{t}=\alpha_{0}+\alpha_{1} D_{t-1}+\beta_{0} \Delta$ log $\#$ districts $t+\beta_{1}$ log \# districts $t_{t-1}+\beta_{2} \Delta$ Upper tier $_{t}+$ $\beta_{3}$ Upper tier $_{t-1}+\varepsilon_{t}$

Model 3:

$\Delta \mathrm{PSI}_{\mathrm{t}}=\alpha_{0}+\alpha_{1} \mathrm{D}_{\mathrm{t}-1}+\beta_{0} \Delta \log$ district magnitude $\mathrm{t}_{\mathrm{t}}+\beta_{1} \log$ district magnitude $\mathrm{t}_{\mathrm{t}-1}+$

$\beta_{2} \Delta$ Upper tier $_{\mathrm{t}}+\beta_{3}$ Upper tier $_{\mathrm{t}-1}+\varepsilon_{\mathrm{t}}$

Model 4:

$\Delta \mathrm{PSI}_{\mathrm{t}}=$

$\alpha_{0}+\alpha_{1} D_{\mathrm{t}-1}+\beta_{0} \Delta$ Decentralization $_{\mathrm{t}}+\beta_{1}$ Decentralization $_{\mathrm{t}-1}+\beta_{2} \Delta \log \#$ districts $_{\mathrm{t}}+$ $\beta_{3} \log \#$ districts $_{\mathrm{t}-1}+\beta_{4} \Delta$ Upper tier $_{\mathrm{t}}+\beta_{5}$ Upper tier $_{\mathrm{t}-1}+\varepsilon_{\mathrm{t}}$

We will use the same specification models to test the robustness of our results with the measure of the Standardized and Weighted Party System Nationalization Score (PSNS).

\section{Results}

Table 4 displays the results of the four different ECMs on Party System Inflation (PSI).

[Table 4 about here]

The estimates of the short-term effects tell us the immediate effect on the PSI of a one unit change in the level of decentralization, the $(\log )$ number of districts, the (log) average district magnitude and the percentage of seats elected in the upper tier in a MMS. The models show that only an increase in the $(\log )$ number of districts elected in the country will have a short-term positive impact on the PSI.

When we take a longer view of changes in party system inflation, we realize that although institutional reforms will barely have any significant impact in the short term, in the mid term and in the long term they will indeed have an effect on party system 
inflation. As could be expected, the (log) number of districts in the country is also relevant in the long term. In addition to this variable, the level of decentralization of the country also appears to be a powerful predictor of party system inflation. Regarding the coefficient for the (log) district magnitude, the variable is significant neither in the short term nor in the long term, but the total long-term effects show that a shift in district magnitude, if any, will have a negative impact on party system inflation. This finding supports the evidence found by Morgenstern et al. (2011) while challenging findings from Cox and Knoll (2003). Finally, a unit change in the percentage of upper seats elected in a MMS appears neither to boost nor to reduce party system inflation in either the short term or the long term.

Figure 1 displays the short-term and the long-term effects of an institutional change for decentralization and the (log) number of districts, based on the results from the pooled model. The dotted line signals the overall impact of the institutional reform on party system inflation. The plots clearly show that, in line with our expectations, a change in the level of decentralization will gradually increase party system inflation, whereas the impact of a unit change in the $(\log )$ number of districts will be also positive but will take place over a shorter time span.

[Figure 1 about here]

Next we test the robustness of our results by running the same ECM on the Party System Nationalization Score (PSNS). We need to remember that this is a measure of nationalization instead of inflation and therefore we expect to encounter the opposite coefficients to the ones seen previously. Table 5 shows the results of these new series of ECMs. 
[Table 5 about here]

The evidence is fairly consistent with the previous findings. In the short term only a change in the (log) number of districts will have an impact on party system nationalization; in the long term, also a change in the degree of decentralization will have a (negative) impact on nationalization. Neither a change in the (log) district magnitude nor in the seats elected in the upper tier will have any substantive impact on our dependent variable either in the short term or the long term. Only a change in the upper tier seems to have a positive total long-term effect, as some literature had indicated.

Figure 2 plots the short-term and the long-term effects of an institutional change for decentralization and the $(\log )$ number of districts on party system nationalization. The two figures are considerably similar to those obtained when assessing party system inflation.

[Figure 2 about here]

Finally, in order to facilitate the understanding of the short-term and the long-term impact of a unit change in the level of decentralization and the (log) number of districts on party system inflation/nationalization, Figure 3 plots the percentage of the total longterm effect achieved by election year after the reform took place. The curve clearly shows that changes in the level of decentralization will affect party system nationalization more gradually than changes in the (log) number of districts. Indeed, the impact in the first year of a change in decentralization levels will represent between 
$10 \%$ (for the PSNS measure) and 30\% (for PSI) of the total change, and $90 \%$ of this total change will not be achieved, respectively, until the $6^{\text {th }}$ election (approximately 25 years later) and the $4^{\text {th }}$ election (20 years later). ${ }^{9}$ Regarding the change in the first year for the (log) number of districts, this will represent $70 \%$ (PSNS) and 65\% (PSI) of the total change, while $90 \%$ of this total change will be achieved in both cases in 3 elections (14 and 12 years, respectively). ${ }^{10}$

[Figure 3 about here]

The argument can be easily understood if we take the case of Italy, a polity that has undergone several institutional reforms, as an example. In Italy, according to the 1948 constitution, there were only five regions with directly elected governments; in 1970, a constitutional reform expanded the number of elected regions to 20 and provided them with powers in urban planning, health, education or culture (Hooghe et al., 2010). According to the expectations suggested above, the party system should have progressively denationalized over subsequent elections. Indeed, the case fits well with our expectations and findings. The emergence of important regionalist parties like the Lega Nord, among others, took place in 1991, two decades after the decentralization reform. The party was founded as the amalgamation of several regional parties, the most important of which were the Lombard League and the Venetian League, both founded during the Eighties (Diamanti, 1996; Giordano, 2000). The Lega Nord took advantage of the pre-existing regional institutions to deploy a new regionalist discourse for the north of Italy, the so-called "Padania" (Biorcio, 1997), which eventually denationalized the Italian party system. 
A second important institutional reform took place several years later, in this case affecting the electoral system. In 1993, Italy introduced a mixed member system called the Legge Mattarella. In it, 475 seats (75\% of the total) were distributed through plurality rule, while the rest were allocated in 26 multimember regional districts with a national threshold of $4 \%$ of the votes (D'Alimonte, 2005; Richard S Katz and Mair, 1995). Considering that the number of districts increased, we would expect coordination among political parties to decrease. Evidence suggests, again, that this was the case. During the period in which this MMS was used, the level of nationalization of the party system quickly changed. Indeed, although $80 \%$ of the constituencies moved to a bipolar competition from 1994 to 1996 (Reed, 2001), the local parties were mostly the ones that survived (R. S. Katz, 1996), thus depleting party system nationalization.

\section{Conclusions}

Institutional arrangements play a crucial role in determining levels of party system nationalization. Despite political scientists' growing interest in this field during recent years, empirical evidence still provides numerous conflictive results. The literature, moreover, has mainly approached the phenomenon through pooled time-series crossnational analysis, thus overlooking the possibility of changes taking place over large periods of elections. In contrast, our approach to the topic using error-correction models allows us to assess both the short-term and the long-term impact of institutional changes on party system nationalization.

We make use of data from the Electoral System Changes in Europe (ESCE), a project which encompasses 22 European countries and up to 263 elections, beginning with the second election after WWII and up to 2012. We include both major and minor reforms, thus increasing the number of changes in institutional designs studied. We test 
our arguments using a measure of party system inflation and check the robustness of our findings with a dispersion measure.

In the end, as we were expecting, the ECM provides us with clear evidence in favour of decentralization reforms depleting party system nationalization; but evidence stresses that its effect is stronger in the long run. This is a relevant finding since it challenges our current understanding of the relationship between political decentralization and party system nationalization. It suggests that the hitherto null relationship found by most of the literature may be explained by fact that cross-sectional analyses are focused on a single point in time. The models also show us that increasing the number of districts will also have a constraining effect on the nationalization of the party system, particularly in the short run. In contrast, changes in district magnitude appear to have no significant effect on the aggregation of party systems, while changes in the percentages of seats in an upper tier do not seem to increase party system nationalization, as some scholars had shown previously.

To sum up, this paper has shown that some institutional reforms may affect party systems immediately, but others can have their effects diffused over subsequent elections. Scholars focusing on the effect of institutions on party systems have largely relied on comparisons across countries, thus leading to quite a pessimistic view of institutional changes being able to drive real movements in political representation. However, cross-country comparisons are flawed if they do not consider dynamic changes within countries over time. Political actors tend to adapt their behaviours to the new institutional environments, but far from being immediate changes, these often occur over longer periods. Future studies on electoral institutions should develop the idea that in order to better understand institutional changes, the short-term and longterm effects should be considered simultaneously. 


\title{
Notes
}

\begin{abstract}
${ }^{1}$ Demand-side explanation of party system nationalization is based on the impact of territorial cleavages. The nationalization of party systems has been explained by the progressive erosion of the pre-industrial cleavages and the increasing importance of the socio-economic one that took place during the 19th century and the beginning of the 20th (Caramani, 2004). However, the nationalization process has been
\end{abstract} weaker in societies with relevant territorial cleavages - mainly ethnic or linguistic- (Bochsler, 2010a, 2010b; Sikk and Bochsler, 2008) for two different reasons. First, because local parties have incentives to compete on their own, representing their territorial electorates; second, because ethno-regional representation is incompatible with merging with parties from other districts, thus leading to a territorially disconnected party system (Clark and Golder, 2006; Lago and Montero, 2009).

${ }^{2}$ This rationale is the same as in the case of strategic behaviour under electoral rules. When voters and parties vote and coalesce around M+1 ( $\mathrm{M}$ being district magnitude), the system reaches a Duvergerian equilibrium in which there are no incentives for strategic voting and only viable parties are expected to compete.

${ }^{3}$ The effective number of parties is calculated as follows: ENP $=\frac{1}{\sum_{i=1}^{n} p_{i}^{2}}$, where $p$ is the proportion of votes obtained by party $i$ in the election (Laakso and Taagepera, 1979).

${ }^{4} \mathrm{We}$ exclude foundational elections. The first post-war elections were often held to elect members of constituent assemblies; these often contemplated changes in the electoral rules (most notably assembly size) in a context of extreme uncertainty.

${ }^{5}$ The reform of 1993 established a mixed member majoritarian system where $75 \%$ of the seats were allocated in single-member districts, while the remaining $25 \%$ were allocated through proportional representation. The linkage between the two tiers was made via the scorporo. In the assignment of PR seats "the 'effective vote' is calculated by subtracting, from the list's total vote, a number one greater that the votes received by the second-placed candidates in all the SMDs where candidates affiliated with that list have won seats" (D'Alimonte, 2005, p. 257). This effective vote determined the PR seats for each list according to the LR-Hare method only when the list received more than $4 \%$ of the vote at the national level.

${ }^{6}$ Many reforms take place out of an election year. The strategy followed has been to place the reform as linked to the first election where this decentralization reform is applied. 
${ }^{7}$ ECMs are, by definition, based on the analysis of changing figures across time and, as a consequence, they do not allow estimations of time-invariant variables. In our case, ethnolinguistic heterogeneity has been shown to be a powerful predictor of party system nationalization (Bochsler, 2010b; Caramani, 2004; Simón, 2013) but its time-invariant character is not suitable for our estimation procedure. Despite this, the country's fixed effects allow the ECM to properly account for systematic differences in party system nationalization explained by the different levels of ethnolinguistic heterogeneity in each country.

${ }^{8}$ Grant and Lebo (2016) have recently criticised the usual way through which ECMs have been estimated - the General Error Correction Model (GECM) suggested by De Boef and Keele (2008). In a nutshell, the authors argue that GECMs tend to overestimate long-term effects. In order to test the robustness of our results we have re-estimated our models with a time series cross-sectional analysis using a panelcorrected standard error (PCSE). The empirical evidence suggests that results obtained through the GECM underestimate the effects of institutional changes as compared to a PCSE, the conventional method which most scholars have relied upon to date. Further details are presented in the results section.

${ }^{9}$ In order to better understand the impact of institutional changes on the number of years, instead on the number of elections, we have estimated the same models in a new database where the units of analysis are years rather than elections. In non-election years, we have filled in the information from the previous election. The results are totally in accordance with the ones using the number of elections as a unit on analysis. Results will be provided by the authors upon request.

${ }^{10}$ As mentioned earlier, we have evaluated the robustness of our results using a PCSE model. PCSE models do not allow for a proper assessment of the short-term and the long-term effects of institutional changes. However, the analysis of the immediate effects of institutional changes provides even stronger evidence than through ECMs. Indeed, both the degree of decentralization and the (log of the) number of districts are statistically significant and in the same direction as the ECM. Additionally, evidence using PCSE also supports the idea -not backed in the ECM- that the (log of the) district magnitude has a positive and significant effect on party system nationalization. Finally, the evidence concerning the presence of an upper tier is mixed, but points to a positive relationship with party system nationalization. The results are consistent also when accounting for time-series dependencies (autocorrelation) through the use of the lagged dependent variable in the right-hand side of the equation, as suggested by Beck and Katz (1995). Results will be made available by the authors upon request. 


\section{References}

Andrews, J. T. and Jackman, R. W. (2005) Strategic fools: electoral rule choice under extreme uncertainty, Electoral Studies, 24 (1), pp. 65-84.

Beck, N. and Katz, J. N. (1995) What to do (and not to do) with Time-Series CrossSection Data, The American Political Science Review, 89 (3), pp. 634-647.

Bedock, C. (2015) Short-term matters: the determinants of reforms of the core democratic rules, European Political Science Review, pp. 1-21.

Benoit, K. (2007) Electoral Laws as Political Consequences: Explaining the Origins and Change of Electoral Institutions, Annual Review of Political Science, 10 (1), pp. 363-390.

Best, R. E. (2012) The long and the short of it: Electoral institutions and the dynamics of party system size, 1950-2005, European Journal of Political Research, 51 (2), pp. 141-165.

Bewley, R. A. (1979) The direct estimation of the equilibrium response in a linear dynamic model, Economics Letters, 3 (4), pp. 357-361.

Biorcio, R. (1997) La Padania promessa. Milano: Il Saggiatore.

Bochsler, D. (2010a) Measuring party nationalisation: A new Gini-based indicator that corrects for the number of units, Electoral Studies, 29 (1), pp. 155-168.

Bochsler, D. (2010b) The Nationalisation of Post-Communist Party Systems, EuropeAsia Studies, 62 (5), pp. 807-827.

Bochsler, D. (2016) The strategic effect of the plurality vote at the district level, Electoral Studies. DOI:10.1016/j.electstud.2016.11.019.

Bowler, S. and Donovan, T. (2013) The Limits of Electoral Reform. Oxford: Oxford University Press.

Brancati, D. (2008) The Origins and Strengths of Regional Parties, British Journal of 
Political Science, 38 (1), pp. 135-159.

Caramani, D. (2004) The Nationalization of Politics: the Formation of National Electorates and Party Systems in Western Europe. Cambridge: Cambridge University Press.

Chhibber, P. K. and Kollman, K. (1998) Party Aggregation and the Number of Parties in India and the United States, The American Political Science Review, 92 (2), pp. $329-342$.

Chhibber, P. K. and Kollman, K. (2004) The Formation of national party systems: federalism and party competition in Canada, Great Britain, India, and the United States. Princeton: Princeton University Press.

Clark, W. R. and Golder, M. (2006) Rehabilitating Duverger's Theory: Testing the Mechanical and Strategic Modifying Effects of Electoral Laws, Comparative Political Studies, 39 (6), pp. 679-708.

Colomer, J. M. (2005) It's parties that choose electoral systems (or, Duverger's laws upside down), Political Studies, 53 (1), pp. 1-21.

Cox, G. W. (1997) Making votes count: strategic coordination in the World's Electoral Systems. Cambridge: Cambridge University Press.

Cox, G. W. (1999) Electoral rules and electoral coordination, Annual Review of Political Science, 2 (1), pp. 145-161.

Cox, G. W. and Knoll, J. S. (2003) Ethnes, fiscs and electoral rules: The determinants of party system inflation., Paper Presented at the Annual Meeting of the American Political Science Association. Philadelphia, PA.

D'Alimonte, R. (2005) Italy: a case of fragmented bipolarism, in: Gallagher, M. and Mitchell, P. (eds.) The politics of electoral systems. Oxford: Oxford University Press, pp. 253-276. 
De Boef, S. and Keele, L. (2008) Taking Time Seriously, American Journal of Political Science, 52 (1), pp. 184-200.

de Miguel, C. (2016) The role of electoral geography in the territorialization of party systems, Electoral Studies. DOI:10.1016/j.electstud.2016.11.013.

Deschouwer, K. (2006) Political Parties as Multi-Level Organizations, in: Katz, R. S. and Crotty, W. (eds.) Handbook of Party Politics. London: Sage, pp. 291-300.

Diamanti, I. (1996) The Northern League: From regional party to party of government, in: Gundle, S. and Parker, S. (eds.) The New Italian Republic: From the Fall of the Berlin Wall to Berlusconi. London and New York: Routledge, pp. 113-129.

Duverger, M. (1954) Political parties: their organization and activity in the modern state. New York: John Willey.

Falcó-Gimeno, A. and Verge, T. (2013) Coalition Trading in Spain: Explaining Statewide Parties' Government Formation Strategies at the Regional Level, Regional \& Federal Studies, 23 (4), pp. 387-405.

Giordano, B. (2000) Italian regionalism or 'Padanian' nationalism - the political project of the Lega Nord in Italian politics, Political Geography, 19 (4), pp. 445-471.

Golosov, G. V. (2016a) Factors of party system nationalization, International Political Science Review, 37 (2), pp. 246-260.

Golosov, G. V (2016b) Party system nationalization. The problems of measurement with an application to federal states, Party Politics, 22 (3), pp. 278-288. DOI:10.1177/1354068814549342.

Grant, T. and Lebo, M. J. (2016) Error Correction Methods with Political Time Series, Political Analysis, 24 (1), pp. 3-30.

Guinjoan, M. (2014) Parties, Elections and Electoral Contests; Competition and Contamination Effects. Farnham: Ashgate/Gower. 
Harbers, I. (2010) Decentralization and the Development of Nationalized Party Systems in New Democracies: Evidence From Latin America, Comparative Political Studies, 43 (5), pp. 606-627.

Hicken, A. and Stoll, H. (2016) Legislative policy-making authority, party system size, and party system nationalization, Electoral Studies. DOI:10.1016/j.electstud.2016.11.017.

Hooghe, L., Marks, G. and Schakel, A. H. (2010) The Rise of Regional Authority: A Comparative Study of 42 Democracies (1950-2006). London: Routledge.

Hooghe, L., Schakel, A. H. and Marks, G. (2008) Appendix B: Country and Regional Scores, Regional \& Federal Studies, 18 (2), pp. 259-274.

Jacobs, K. and Leyenaar, M. (2011) A Conceptual Framework for Major, Minor, and Technical Electoral Reform, West European Politics, 34 (3), pp. 495-513.

Jesse, N. G. (1999) Candidate success in multi-member districts: an investigation of Duverger and Cox, Electoral Studies, 18 (3), pp. 323-340.

Jones, M. P. and Mainwaring, S. (2003) The Nationalization of Parties and Party Systems: An Empirical Measure and an Application to the Americas, Party Politics, 9 (2), pp. 139-166.

Kasuya, Y. and Moenius, J. (2008) The nationalization of party systems: Conceptual issues and alternative district-focused measures, Electoral Studies, 27 (1), pp. $126-135$.

Katz, R. S. (1996) Electoral Reform and the Transformation of Party Politics in Italy, Party Politics, 2 (1), pp. 31-53.

Katz, R. S. and Mair, P. (1995) Changing Models of Party Organization and Party Democracy, Party Politics, 1 (1), pp. 5-28.

Laakso, M. and Taagepera, R. (1979) Effective'’ Number of Parties: A Measure with 
Application to West Europe, Comparative Political Studies, 12 (1), pp. 3-27.

Lago-Peñas, I. and Lago-Peñas, S. (2011) Decentralization and the nationalization of party systems, Environment and Planning C: Government and Policy, 29 (2), pp. 244-263.

Lago, I. and Montero, J. R. (2009) Coordination between electoral arenas in multi-level countries, European Journal of Political Science, 48 (2), pp. 176-203.

Lago, I. and Montero, J. R. (2014) Defining and measuring party system nationalization, European Political Science Review, 6 (2), pp. 191-211.

León, S. (2012) How do citizens attribute responsibility in multilevel states? Learning, biases and asymmetric federalism. Evidence from Spain, Electoral Studies, 31 (1), pp. $120-130$.

Lublin, D. (2016) Electoral systems, ethnic diversity and party systems in developing democracies, Electoral Studies. DOI:10.1016/j.electstud.2016.11.012.

Moenius, J. and Kasuya, Y. (2004) Measuring Party Linkage across Districts: Some Party System Inflation Indices and their Properties, Party Politics, 10 (5), pp. $543-564$.

Morgenstern, S., Swindle, S. M. and Castagnola, A. (2011) Party Nationalization and Institutions, The Journal of Politics.

Nikolenyi, C. (2009) Party Inflation in India: Why has a Multiparty Format Prevailed in the National Party System?, in: Grofman, B., Blais, A., and Bowler, S. (eds.) Duverger's Law of Plurality Voting. New York: Springer,.

Reed, S. R. (2001) Duverger's Law is Working in Italy, Comparative Political Studies, 34 (3), pp. 312-327.

Remmer, K. L. (2008) The Politics of Institutional Change Electoral Reform in Latin America, 1978-2002, Party Politics, 14 (1), pp. 5-30. 
Riera, P. (2013) Electoral systems and the Sheriff of Nottingham: Determinants of disproportionality in new and established democracies, Party Politics, 21 (2), pp. $222-233$.

Rokkan, S. (1970) Citizens, Elections, Parties: Approaches to the Comparative Study of the Processes of Development. Oslo: Universitetsforlaget.

Schattschneider, E. E. (1960) The semisovereign People: A Realist's View of Democracy in America. Boston: Wadsworth.

Sikk, A. and Bochsler, D. (2008) Impact of Ethnic Heterogeneity on Party Nationalization in the Baltic States. The Nationalisation of Party Systems in Central and Eastern Europe.

Simón, P. (2013) The Combined Impact of Decentralisation and Personalism on the Nationalisation of Party Systems, Political Studies, 61, pp. 24-44.

Simón, P. (2016) Heterogeneity in turnout rates across regions and the nationalization of party systems, Acta Politica, 51, pp. 173-193.

Tavits, M. (2008) On the linkage between electoral volatility and party system instability in Central and Eastern Europe, European Journal of Political Research, 47, pp. 537-555. 
Tables

Table 1.Expected impact and speed of reforms on party system nationalization

\begin{tabular}{ccc}
\hline & \multicolumn{2}{c}{ Impact } \\
& Positive & Negative \\
\cline { 2 - 4 } Speed & Upper Tier & Decentralization \\
\cline { 2 - 3 } & Quick & \multicolumn{2}{c}{$\begin{array}{c}\text { Number of districts } \\
\text { District Magnitude }\end{array}$} \\
\hline
\end{tabular}


Table 2. Changes in decentralization and in the electoral system across countries

\begin{tabular}{lcccccc}
\hline \multicolumn{1}{c}{ Country } & $\begin{array}{c}\text { First } \\
\text { election }\end{array}$ & $\begin{array}{c}\text { \#Number } \\
\text { of } \\
\text { elections }\end{array}$ & $\begin{array}{c}\Delta \text { Decentra- } \\
\text { lization }\end{array}$ & $\begin{array}{c}\Delta \# \text { of } \\
\text { districts }\end{array}$ & $\begin{array}{c}\Delta \text { District } \\
\text { Magnitude }\end{array}$ & $\begin{array}{c}\Delta \text { Upper } \\
\text { Tier }\end{array}$ \\
\hline Austria & 1953 & 18 & 1 & 2 & 1 & 17 \\
Belgium & 1950 & 15 & 3 & 1 & 1 & 0 \\
Czech Republic & 1996 & 4 & 1 & 1 & 1 & 2 \\
Denmark & 1950 & 24 & 2 & 2 & 5 & 2 \\
Estonia & 1999 & 2 & 0 & 1 & 0 & 0 \\
Finland & 1951 & 16 & 1 & 0 & 0 & 0 \\
France & 1973 & 8 & 2 & 6 & 2 & 0 \\
Germany & 1957 & 15 & 4 & 1 & 12 & 0 \\
Greece & 1981 & 8 & 2 & 0 & 0 & 0 \\
Hungary & 1998 & 4 & 1 & 0 & 0 & 0 \\
Iceland & 1949 & 15 & 0 & 1 & 2 & 2 \\
Ireland & 1951 & 17 & 2 & 5 & 6 & 0 \\
Italy & 1953 & 12 & 6 & 2 & 4 & 6 \\
Netherlands & 1952 & 18 & 1 & 0 & 1 & 0 \\
Norway & 1953 & 15 & 1 & 2 & 5 & 2 \\
Poland & 1993 & 4 & 1 & 3 & 2 & 1 \\
Portugal & 1979 & 11 & 2 & 1 & 2 & 0 \\
Romania & 1996 & 2 & 1 & 0 & 2 & 0 \\
Spain & 1982 & 9 & 3 & 0 & 0 & 0 \\
Sweden & 1952 & 18 & 1 & 1 & 3 & 2 \\
Switzerland & 1951 & 12 & 0 & 1 & 3 & 0 \\
United Kingdom & 1951 & 16 & 4 & 7 & 0 & 0 \\
\hline TOTAL & & $\mathbf{2 6 3}$ & $\mathbf{3 9}$ & $\mathbf{3 7}$ & $\mathbf{5 2}$ & $\mathbf{3 4}$ \\
\hline & & & & & &
\end{tabular}


Table 3. Summary statistics

\begin{tabular}{lccccc}
\hline & Observations & Mean & $\begin{array}{c}\text { Standard } \\
\text { deviation }\end{array}$ & Min & Max \\
\hline Inflation & 263 & 0.134 & 0.129 & 0.001 & 0.698 \\
PSNS & 263 & 0.797 & 0.091 & 0.498 & 0.945 \\
\hline Regional Authority & 263 & 9.941 & 7.468 & 0.000 & 32.200 \\
(log) Number of districts & 263 & 3.357 & 1.435 & 0.000 & 6.491 \\
(log) District Magnitude & 263 & 2.172 & 1.116 & 0.000 & 5.011 \\
Upper Tier & 258 & 9.006 & 14.048 & 0.000 & 60.660 \\
\hline
\end{tabular}


Table 4. The determinants of party inflation

\begin{tabular}{|c|c|c|c|c|}
\hline & $\begin{array}{c}\text { Decentralization } \\
\text { (1) }\end{array}$ & $\begin{array}{c}\text { Electoral systems } \\
\text { (2) }\end{array}$ & $\begin{array}{c}\text { Electoral systems } \\
\text { (3) }\end{array}$ & Pooled (4) \\
\hline \multicolumn{5}{|l|}{ Short-term effects } \\
\hline$\Delta$ Decentralization & $\begin{array}{c}0.002 \\
(0.003)\end{array}$ & & & $\begin{array}{c}0.001 \\
(0.003)\end{array}$ \\
\hline$\Delta(\log ) \#$ districts & & $\begin{array}{c}0.097 * * * \\
(0.014)\end{array}$ & & $\begin{array}{c}0.100 * * * \\
(0.014)\end{array}$ \\
\hline$\Delta(\log ) \mathrm{DM}$ & & & $\begin{array}{l}-0.006 \\
(0.020)\end{array}$ & \\
\hline$\Delta$ Upper tier & & $\begin{array}{l}-0.001 \\
(0.001)\end{array}$ & $\begin{array}{c}0.002 \\
(0.001)\end{array}$ & $\begin{array}{c}-0.002 \\
(0.001)\end{array}$ \\
\hline \multicolumn{5}{|l|}{ Long-term effects } \\
\hline Inflation $_{t-1}$ & $\begin{array}{l}-0.283 * * * \\
(0.058)\end{array}$ & $\begin{array}{c}-0.290 * * * \\
(0.050)\end{array}$ & $\begin{array}{c}-0.265 * * * \\
(0.051)\end{array}$ & $\begin{array}{c}-0.308 * * * \\
(0.058)\end{array}$ \\
\hline Decentralization $_{\mathrm{t}-1}$ & $\begin{array}{c}0.006 * * * \\
(0.002)\end{array}$ & & & $\begin{array}{c}0.004 * * \\
(0.002)\end{array}$ \\
\hline$(\log ) \#$ districts ${ }_{t-1}$ & & $\begin{array}{l}0.040^{*} \\
(0.016)\end{array}$ & & $\begin{array}{l}0.045^{* *} \\
(0.016)\end{array}$ \\
\hline$(\log ) \mathrm{DM}_{\mathrm{t}-1}$ & & & $\begin{array}{l}-0.016 \\
(0.018)\end{array}$ & \\
\hline Upper tier ${ }_{t-1}$ & & $\begin{array}{l}-0.000 \\
(0.001)\end{array}$ & $\begin{array}{l}0.001+ \\
(0.001)\end{array}$ & $\begin{array}{l}-0.000 \\
(0.001)\end{array}$ \\
\hline \multicolumn{5}{|l|}{ Total long-term effects } \\
\hline Decentralization & $\begin{array}{c}0.022 * * * \\
(0.002)\end{array}$ & & & $\begin{array}{c}0.013 * * * \\
(0.001)\end{array}$ \\
\hline$(\log ) \#$ districts & & $\begin{array}{c}0.138 * * * \\
(0.014)\end{array}$ & & $\begin{array}{c}0.145^{* * *} \\
(0.014)\end{array}$ \\
\hline$(\log ) \mathrm{DM}$ & & & $\begin{array}{c}-0.059 * * * \\
(0.017)\end{array}$ & \\
\hline Upper tier & & $\begin{array}{l}-0.001 \\
(0.001)\end{array}$ & $\begin{array}{c}0.005 * * * \\
(0.001)\end{array}$ & $\begin{array}{c}-0.001+ \\
(0.001)\end{array}$ \\
\hline Constant & $\begin{array}{l}-0.023 \\
(0.017)\end{array}$ & $\begin{array}{c}-0.089+ \\
(0.046)\end{array}$ & $\begin{array}{c}0.060 \\
(0.039)\end{array}$ & $\begin{array}{c}-0.143 * * \\
(0.052)\end{array}$ \\
\hline Observations & 253 & 245 & 244 & 236 \\
\hline$R^{2}$ & 0.109 & 0.271 & 0.121 & 0.282 \\
\hline
\end{tabular}

Standard errors in parentheses

$+\mathrm{p}<0.1, * \mathrm{p}<0.05, * * \mathrm{p}<0.01, * * * \mathrm{p}<0.001$ 
Table 5. The determinants of party system nationalization (PSNS)

\begin{tabular}{|c|c|c|c|c|}
\hline & $\begin{array}{c}\text { Decentralization } \\
\text { (1) }\end{array}$ & $\begin{array}{c}\text { Electoral systems } \\
\text { (2) }\end{array}$ & $\begin{array}{l}\text { Electoral systems } \\
\text { (3) }\end{array}$ & Pooled (4) \\
\hline \multicolumn{5}{|l|}{ Short-term effects } \\
\hline$\Delta$ Decentralization & $\begin{array}{l}-0.003 \\
(0.002)\end{array}$ & & & $\begin{array}{l}-0.003 \\
(0.002)\end{array}$ \\
\hline$\Delta(\log ) \#$ districts & & $\begin{array}{c}-0.034 * * \\
(0.011)\end{array}$ & & $\begin{array}{c}-0.032 * * \\
(0.011)\end{array}$ \\
\hline$\Delta(\log ) \mathrm{DM}$ & & & $\begin{array}{l}-0.011 \\
(0.015)\end{array}$ & \\
\hline$\Delta$ Upper tier & & $\begin{array}{c}0.000 \\
(0.001)\end{array}$ & $\begin{array}{l}-0.001 \\
(0.001)\end{array}$ & $\begin{array}{c}0.000 \\
(0.001)\end{array}$ \\
\hline \multicolumn{5}{|l|}{ Long-term effects } \\
\hline Inflation $_{\mathrm{t}-1}$ & $\begin{array}{c}-0.354 * * * \\
(0.061)\end{array}$ & $\begin{array}{c}-0.348 * * * \\
(0.050)\end{array}$ & $\begin{array}{c}-0.330 * * * \\
(0.050)\end{array}$ & $\begin{array}{c}-0.385 * * * \\
(0.057)\end{array}$ \\
\hline Decentralization $_{\mathrm{t}-1}$ & $\begin{array}{c}-0.005^{* * *} * \\
(0.001)\end{array}$ & & & $\begin{array}{c}-0.004 * * \\
(0.001)\end{array}$ \\
\hline$(\log ) \#$ districts ${ }_{t-1}$ & & $\begin{array}{l}-0.017 \\
(0.011)\end{array}$ & & $\begin{array}{l}-0.020 \\
(0.012)\end{array}$ \\
\hline$(\log ) \mathrm{DM}_{\mathrm{t}-1}$ & & & $\begin{array}{c}0.002 \\
(0.013)\end{array}$ & \\
\hline Upper tier ${ }_{t-1}$ & & $\begin{array}{c}0.001 \\
(0.001)\end{array}$ & $\begin{array}{c}0.000 \\
(0.001)\end{array}$ & $\begin{array}{c}0.001 \\
(0.001)\end{array}$ \\
\hline \multicolumn{5}{|l|}{ Total long-term effects } \\
\hline Decentralization & $\begin{array}{l}-0.014 * * * \\
(0.001)\end{array}$ & & & $\begin{array}{c}-0.009 * * * \\
(0.001)\end{array}$ \\
\hline$(\log ) \#$ districts & & $\begin{array}{c}-0.049 * * * \\
(0.011)\end{array}$ & & $\begin{array}{c}-0.051 * * * \\
(0.011)\end{array}$ \\
\hline$(\log ) \mathrm{DM}$ & & & $\begin{array}{c}0.005 \\
(0.013)\end{array}$ & \\
\hline Upper tier & & $\begin{array}{c}0.002 * * * \\
(0.001)\end{array}$ & $\begin{array}{l}0.000 \\
(0.001)\end{array}$ & $\begin{array}{c}0.002 * * * \\
(0.001)\end{array}$ \\
\hline Constant & $\begin{array}{c}0.335 * * * \\
(0.056) \\
\end{array}$ & $\begin{array}{c}0.328 * * * \\
(0.061)\end{array}$ & $\begin{array}{c}0.260 * * * \\
(0.045)\end{array}$ & $\begin{array}{c}0.402 * * * \\
(0.072) \\
\end{array}$ \\
\hline Observations & 253 & 245 & 244 & 236 \\
\hline$R^{2}$ & 0.138 & 0.204 & 0.176 & 0.207 \\
\hline
\end{tabular}

Standard errors in parentheses

$+\mathrm{p}<0.1, * \mathrm{p}<0.05, * * \mathrm{p}<0.01, * * * \mathrm{p}<0.001$ 


\section{Figures}

Figure 1. The total long-term effects of a change in the level of decentralization on party system inflation

Decentralization

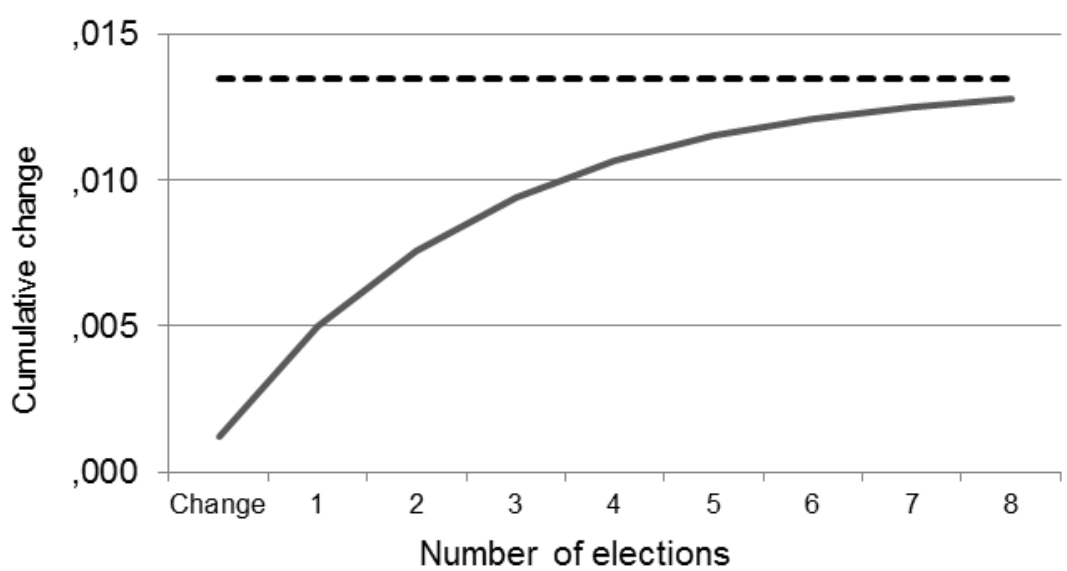

(Log) Number of districts

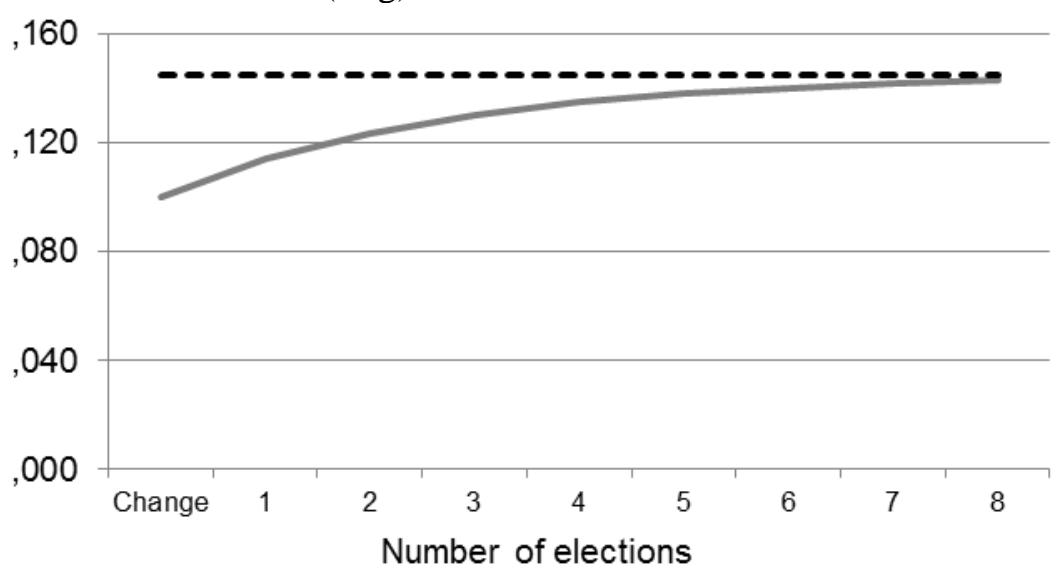

Figure 2. The total long-term effects of the level of decentralization on party system nationalization (PSNS)

Decentralization

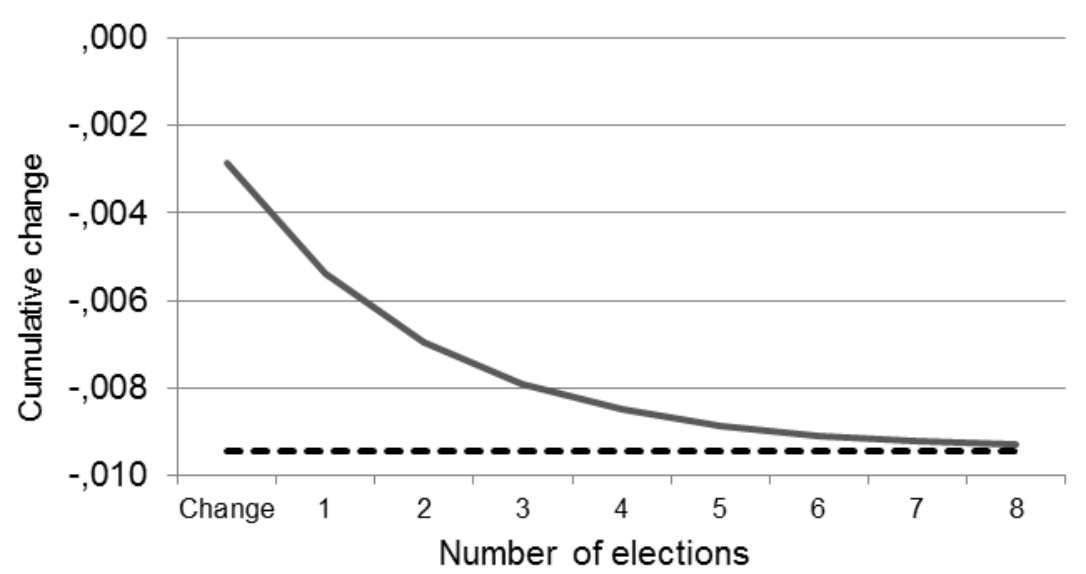

(Log) Number of districts

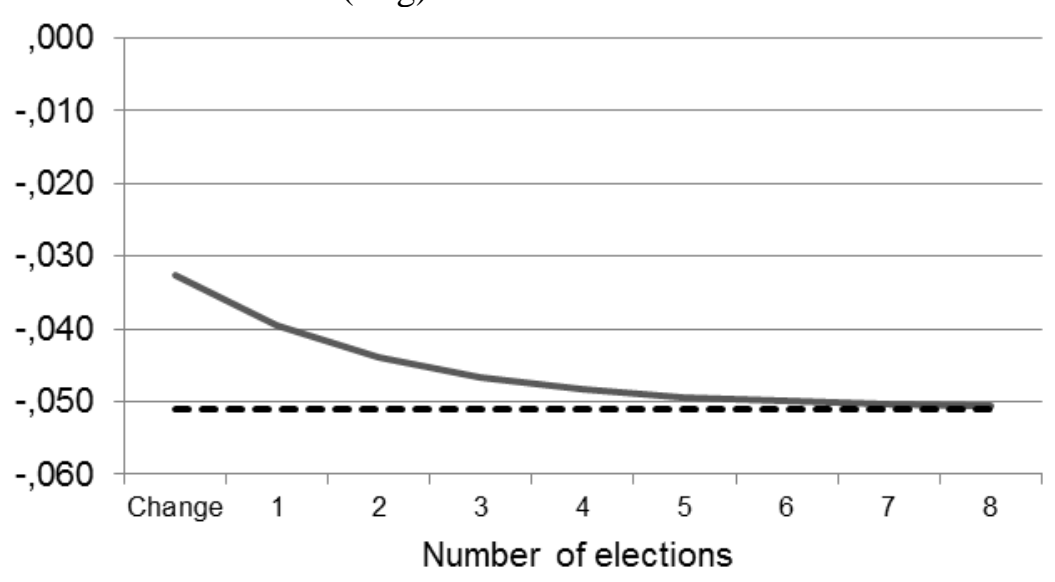


Figure 3. Percentage of the total long-term effect achieved by year after reform

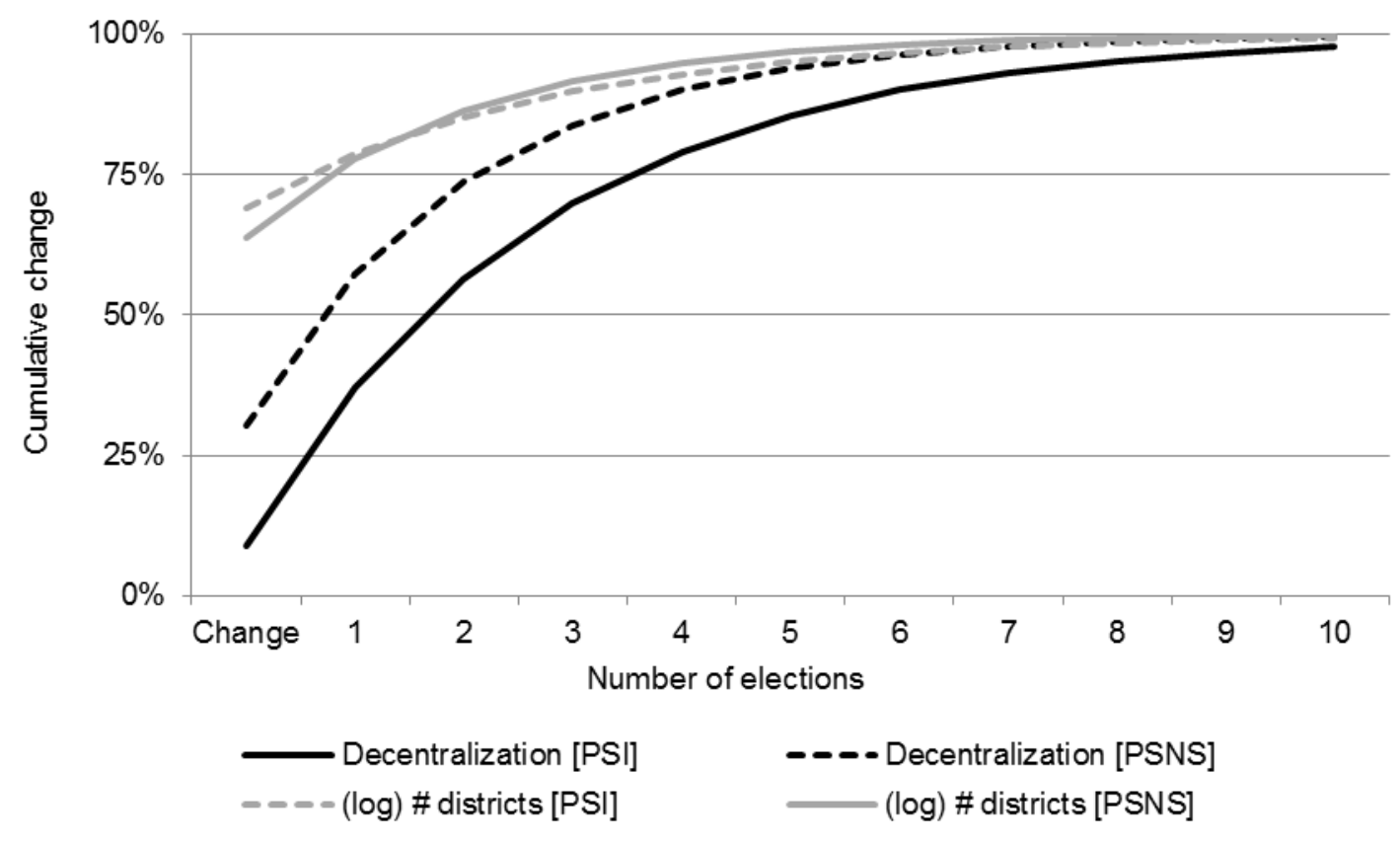

